\title{
Diseminasi Informasi Terkait Metode Kontrasepsi Jangka Panjang pada Masyarakat Desa Bunut Baok, Lombok Tengah
}

\author{
Herpan Syafii Harahap ${ }^{1}$, Ario Danianto ${ }^{1}$, Abdurrachim², Baiq Dewi Sartika ${ }^{2}$, Paniatul Hiwala ${ }^{2}$, \\ Luh Made Ita Purwani ${ }^{3}$, Ni Wayan Sekar Ratih ${ }^{3}$, Nurarafah Andika Putri ${ }^{3}$, Sri Susilawatin ${ }^{3}$, \\ Muhammad Azrul Uzmi ${ }^{4}$, Rifky Maulana Ackbar ${ }^{5}$, Vinni Dianggita $^{6}$ \\ ${ }^{1}$ Fakultas Kedokteran, Universitas Mataram, Mataram, Indonesia \\ ${ }^{2}$ Fakultas Pertanian, Universitas Mataram, Mataram, Indonesia \\ ${ }^{3}$ Fakultas Keguruan dan Ilmu Pendidikan, Universitas Mataram, Mataram, Indonesia \\ ${ }^{4}$ Fakultas Peternakan, Universitas Mataram, Mataram, Indonesia \\ ${ }^{5}$ Fakultas Hukum, Universitas Mataram, Mataram, Indonesia \\ ${ }^{6}$ Fakultas Ilmu Teknologi Pangan dan Agroindustri, Universitas Mataram, Mataram, Indonesia
}

\section{Article history}

Received: 25-07-2020

Revised: 19-08-2020

Accepted: 26-08-2020

*Corresponding Author:

Herpan Syafii Harahap,

Departemen Neurologi,

Fakultas Kedokteran

Universitas Mataram, Mataram,

Indonesia;

Email:

herpanharahap@unram.ac.id
Abstract: Indonesia is the fourth most populous country in the world. In 2015, the population growth rate in West Nusa Tenggara is equal with national population growth rate, which is about $1.39 \%$. The long-term contraceptive methods is one of the most effective family planning programs to succeed in controlling the population growth rate. The participation rate for the use of this contraceptive methods by fertile age couples in Bunut Baok village, Middle Lombok, is only about $10 \%$. This was dissemination of information event aimed to disseminate the information regarding long-term contraceptive methods to Bunut Baok villagers, Middle of Lombok. This social event is part of the thematic Kuliah Kerja Nyata (KKN) programs of students of Universitas Mataram in the period of 2020 in Bunut Baok villagers attended by 59 Bunut Baok villagers as participants. In this event, pre-test and post-test were also conducted to evaluate the increase of their knowledge about long-term contraceptive methods. The participants had mean age of 36 years old, mostly female and had senior high school educational level. The mean of posttest scores was higher than the mean of pretest scores $(88.54 \mathrm{vs} 77.03 ; \mathrm{p}$ $=0.000)$. These results indicated that this dissemination of information event increase the level of knowledge of Bunut Baok villagers related to the long-term contraceptive methods.

Keywords: population; contraception; knowledge; education

Abtrak: Indonesia merupakan negara dengan jumlah penduduk terbesar pada urutan ke 4 di dunia. Provinsi Nusa Tenggara Barat pada Tahun 2015 memiliki laju pertumbuhan penduduk yang sama dengan tingkat nasional, yaitu sebesar $1,39 \%$. Metode kontrasepsi jangka panjang (MKJP) merupakan salah satu program KB yang paling efektif untuk menyukseskan upaya pengendalian laju pertumbuhan penduduk tersebut. Tingkat partisipasi penggunaan MKJP oleh pasangan usia subur di Desa Bunut Baok, Lombok Tengah, masih termasuk rendah, yaitu hanya sekitar $10 \%$. Kegiatan pengabdian ini ditujukan untuk mendiseminasikan informasi terkait MKJP pada masyarakat Desa Bunut Baok, Lombok Tengah. Kegiatan ini merupakan salah satu dari rangkaian kegiatan Kuliah Kerja Nyata Tematik Mahasiswa Universitas Mataram Tahun 2020 di Desa Bunut Baok, yang meliputi kegiatan penyuluhan yang diikuti oleh 59 orang warga Desa Bunut Baok. Dalam 
kegiatan ini juga dilakukan pretest dan posttest untuk mengevaluasi keberhasilan kegiatan, yaitu meningkatnya pengetahuan peserta kegiatan terkait MKJP. Subjek peserta kegiatan ini memiliki rerata usia 36 tahun, sebagian besar memiliki jenis kelamin perempuan dan tingkat pendidikan sekolah menengah atas (SMA). Rerata nilai postest dari 59 subjek yang berpartisipasi dalam kegiatan penyuluhan terkait MKJP ini lebih tinggi dibandingkan dengan rerata nilai pretest mereka $(88,54 \mathrm{vs} 77,03 ; \mathrm{p}=0,000)$. Hasil tersebut menunjukkan bahwa kegiatan penyuluhan terkait MKJP meningkatkan tingkat pengetahuan masyarakat Desa Bunut Baok terkait MKJP.

Kata Kunci: populasi; kontrasepsi; pengetahuan; pendidikan

\section{PENDAHULUAN}

Indonesia merupakan negara dengan jumlah penduduk terbesar pada urutan ke 4 di dunia. Jumlah penduduk Indonesia pada tahun 2015 berdasarkan data Badan Pusat Statistik Indonesia Tahun 2016 sebesar 255,5 juta jiwa dengan laju pertumbuhan penduduk sebesar 1,38\%. Jumlah penduduk di Provinsi Nusa Tenggara Barat sendiri pada tahun yang sama sebesar 4,84 juta jiwa $(1,89 \%$ dari populasi total) dengan laju pertumbuhan penduduk yang sama dengan tingkat nasional, yaitu sebesar 1,39\% (Badan Pusat Statistik, 2016). Tingginya laju pertumbuhan penduduk tersebut dapat disebabkan oleh beberapa faktor, diantaranya adalah penyebaran penduduk yang tidak merata, pernikahan usia dini yang tinggi, dan program KB (Keluarga Berencana) belum berjalan dengan baik.

Tingginya laju pertumbuhan penduduk tersebut, selain memiliki dampak positif, juga memiliki berbagai dampak negatif yang perlu diantisipasi, diantaranya adalah rendahnya tingkat pendidikan dan tingginya tingkat pengangguran penduduk yang berimbas pada tingginya angka kemiskinan penduduk (Agustina et al, 2018). Dibidang kesehatan, kombinasi antara rendahnya tingkat pendidikan dan tingginya tingkat kemiskinan turut berperan terhadap tingginya angka kematian ibu melahirkan dan bayi, stunting, dan gizi kurang pada anak (Muljati et al., 2011; Suryaningsih, 2017). Keseluruhan permasalahan yang timbul akibat tingginya laju pertumbuhan penduduk tersebut pada akhirnya akan menjadi beban bagi masyarakat dan pemerintah.

Salah satu upaya yang dilakukan pemerintah untuk mengendalikan tingginya angka pertumbuhan penduduk adalah melalui program keluarga berencana (KB). Program KB terbukti efektif dalam mengendalikan laju pertumbuhan penduduk (Pasrah et al., 2014). Metode kontrasepsi jangka panjang (MKJP) merupakan salah satu program KB yang paling efektif untuk menyukseskan upaya pengendalian laju pertumbuhan penduduk tersebut (Arifarahmi, 2018). Pada umumnya, pengambilan keputusan mengenai kesediaan dalam berpartisipasi menjadi akseptor KB menggunakan MKJP ditentukan oleh kaum pria sebagai suami. Oleh karena itu, dalam pelaksanaan program tersebut, keterlibatan kaum pria, baik sebagai subjek yang mendorong istrinya untuk menjadi akseptor KB maupun sebagai subjek yang secara langsung berparsisipasi sebagai akseptor KB, menjadi kuci penting keberhasilan program KB MKJP. Untuk mendapatkan partisipasi yang tinggi dari kaum pria tersebut, maka pengetahuan yang mencukupi dan persepsi yang baik pengenai pelaksanaan program KB MKJP menjadi sangat penting (Febriani dan Indrawati, 2016; Samtyaningsih dan Ibaadillah, 2018; Hidayah dan Lubis, 2019). Dengan demikian, diseminasi informasi yang benar dan jangkauan informasi yang luas hingga pada tingkat desa sangat berpengaruh terhadap tingkat pengetahuan dan persepsi masyarakat, terutama kaum pria, terhadap program KB MKJP (Munandar, 2017). 
Tingkat partisipasi masyarakat di Desa Bunut Baok, Lombok Tengah, berdasarkan data yang diperoleh dari Penyuluh Lapangan Keluarga Berecana (PLKB) Desa Bunut Baok Tahun 2017-2018, masih termasuk rendah, yaitu hanya sekitar 277 dari total 2.752 pasangan usia subur (10\%). Jumlah tersebut sama dengan angka partisipasi penduduk usia subur di Provinsi Nusa Tenggara Barat (NTB) (Amran dan Damayanti, 2018). Hasil observasi di lapangan menunjukkan bahwa faktor utama yang mendasari rendahnya partisipasi masyarakat dalam menggunakan MKJP adalah rendahnya tingkat pengetahuan mereka terkait informasi MKJP. Berdasarkan paparan di atas, kegiatan pengabdian masyarakat ini dilaksanakan dengan tujuan untuk mendiseminasikan informasi terkait metode kontrasepsi jangka panjang (MKJP) pada masyarakat Desa Bunut Baok, Lombok Tengah.

\section{METODE}

Kegiatan pengabdian kepada masyarakat ini merupakan salah satu dari rangkaian kegiatan Kuliah Kerja Nyata (KKN) Tematik Mahasiswa Universitas Mataram Tahun 2020 di Desa Bunut Baok, Kecamatan Praya, Kabupaten Lompok Tengah. Kegiatan ini dilaksanakan padan tanggal 11 Januari 2020 di Desa Bunut Baok. Sebanyak 59 orang subjek yang merupakan warga dari 19 dusun yang berada dalam lingkup wilayah Desa Bunut Baok mengikuti rangkaian kegiatan pengabdian kepada masyarakat yang meliputi pretest, penyuluhan dengan topik metode kontrasepsi jangka panjang (MKJP), dan posttest. Kegiatan pretest dilakukan untuk menilai tingkat pengetahuan awal subjek terkait MKJP sebelum mendapatkan penyajian materi penyuluhan. Soal-soal pretest yang diberikan adalah 20 butir soal dengan pilihan jawaban benar atau salah seputar MKJP. Setiap sjawaban yang benar diberikan nilai 5 dan total nilai dari kegiatan pretest ini adalah 100 .

Pada tahap penyuluhan, subjek peserta kegiatan pengabdian kepada masyarakat diberikan materi tentang MKJP dengan metode presentasi menggunakan bantuan power point dan LCD. Materi yang disampaikan secara garis besar meliputi pentingnya program KB, definisi MKJP sebagai bagian dari program $\mathrm{KB}$, jenis-jenis MKJP yang tersedia dan tempat pelayanan kesehatan yang menyediakan pelayanan MKJP yang bisa diakses oleh setiap warga masyarakat Desa Bunut Baok, dan efektivitas, keunggulan, dan kelemahan dari masing-masing jenis MKJP yang tersedia. Materi ini disajikan oleh pakar dibidang tersebut, yaitu seorang dokter spesialis kandungan dan kebidanan dan seorang bidan dari Puskesmas dengan Desa Bunut Baok sebagai salah satu wilayah kerjanya.

Pada tahap posttest, subjek peserta kegiatan penyuluhan diberikan soal-soal yang sama dengan dengan soal-soal yang dberikan pada saat kegiatan pretest setelah kegiatan penyuluhan selesai. Tahap ini dilaksanakan dengan tujuan untuk mengetahui adanya perubahan tingkat pengetahuan subjek peserta kegiatan penyuluhan terkait MKJP. Peningkatan pengetahuan subjek peserta kegiatan penyuluhan terkait MKJP dinilai dari adanya perbedaan rerata nilai pretest dan posttest yang bermakna secara statistik.

\section{HASIL DAN PEMBAHASAN}

Sebanyak 59 orang warga Desa Bunut Baok turut berpartisipasi sebagai peserta dalam kegiatan pengabdian kepada masyarakat yang diprakarsai oleh Mahasiswa KKN Tematik Universitas Mataram Tahun 2020 ini. Warga yang hadir tersebut merupakan representasi dari 19 dusun yang berada dalam wilayah kerja Desa Bunut Baok. Karakteristik umum subjek peserta kegiatan ini 
diantaranya adalah memiliki rerata usia 36 tahun, sebagian besar subjek memiliki jenis kelamin perempuan dan memiliki tingkat pendidikan sekolah menengah atas (SMA) (Tabel 1).

Tabel 1. Karakteristik subjek peserta kegiatan penyuluhan

\begin{tabular}{lll}
\hline Kategori & Sub-kategori & Jumlah $(\mathrm{n}=59)$ \\
\hline Usia dalam tahun, rerata \pm SD* & & $36.61 \pm 7.76$ \\
Jenis kelamin, n(\%) & Laki-laki & $17(28.8)$ \\
& Perempuan & $42(71.2)$ \\
Pendidikan, n(\%) & SD** & $7(11.9)$ \\
& SMP & $17(28.8)$ \\
& SMA & $26(44.1)$ \\
& Sarjana & $9(15.3)$
\end{tabular}

$\mathrm{SD}^{*}=$ standar deviasi; SD**=Sekolah Dasar; SMP=Sekolah Menengah Pertama; SMA=Sekolah Menengah Atas

Seperti yang telah disampaikan sebelumnya, rangkaian kegiatan pengabdian kepada masyarakat ini meliputi pretest, kegiatan penyuluhan, dan posttest. Dalam seluruh rangkaian kegiatan tersebut, seluruh subjek peserta kegiatan menunjukkan antusiasme yang tinggi. Pada tahap penyuluhan, subjek kegiatan ini turut berpartisipasi aktif, terutama dalam sesi diskusi dan tanya jawab (Gambar 1). Dalam kegiatan penyuluhan, materi yang disampaikan meliputi definisi dari MKJP, pengenalan jenis-jenis MKJP beserta efektivitas, keuntungan, dan kerugiannya, serta informasi tempat pelayanan MKJP yang bisa diakses oleh masyarakat Desa Bunut Baok. Secara garis besar, jenis MKJP yang diperkenalkan kepaa subjek peserta penyuluhan antara lain alat kontrasepsi bawah kulit (implan/susuk), alat kontrasepsi dalam rahim, metode operasi pria, dan metode operasi wanita.

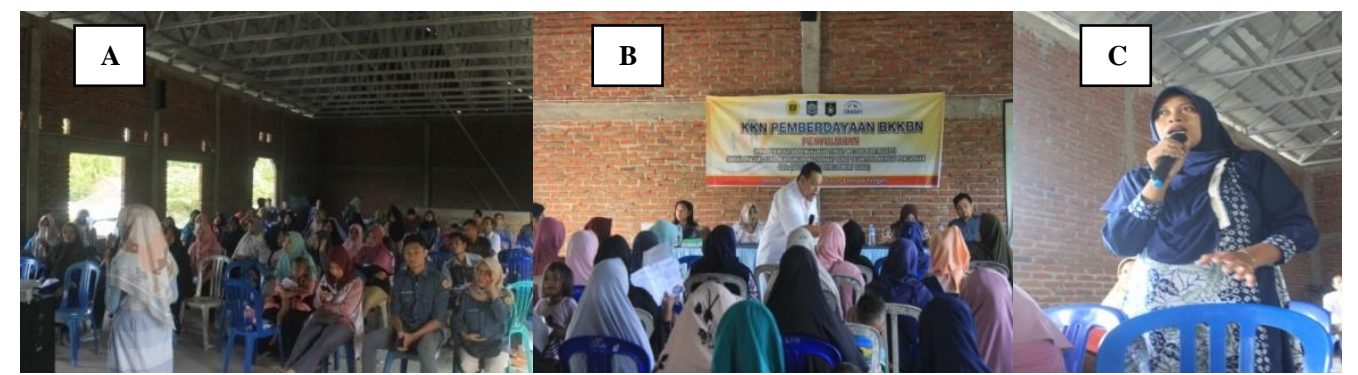

Gambar 1. Rangkaian kegiatan penyuluhan dengan materi terkait MKJP di Aula Desa Bunut Baok. A. Presentasi materi penyuluhan oleh bidan Puskesmas. B. Presentasi materi penyuluhan oleh dokter spesialis kandungan dan kebidanan. C. Sesi tanya jawab.

Rerata nilai postest dari 59 subjek yang berpartisipasi dalam kegiatan penyuluhan terkait MKJP ini lebih tinggi dibandingkan dengan rerata nilai pretest mereka $(88,54$ vs 77,03$)$. Dengan demikian, hasil kegiatan ini menunjukkan bahwa kegiatan penyuluhan terkait MKJP yang dilaksanakan dalam kegiatan pengabdian kepada masyarakat ini berhasil meningkatkan tingkat pengetahuan mereka mengenai MKJP $(\mathrm{p}<0.05)$ (Tabel 2). Mengingat materi yang disampaikan dan pretest maupun posttest yang diberikan termasuk dalam kategori hal baru dan memiliki tingkat kesulitan tersendiri bagi penduduk Desa Bunut Baok, maka keberhasilan kegiatan ini dalam meningkatkan pengetahuan mereka terkait MKJP ditentukan oleh dua faktor penting, yaitu tingkat 
pendidikan peserta yang cukup dan kemampuan untuk memusatkan perhatian dengan baik. Pemilihan subjek peserta penyuluhan dengan tingkat pendidikan mayoritas menengah keatas merupakan langkah tepat dalam mendukung suksesnya kegiatan penyuluhan ini. Dengan tingkat pendidikan yang baik, maka kemampuan partisipan dalam menerima, memahami, dan mengingat informasi yang disampaikan tentunya akan lebih baik dibandingkan dengan mereka yang memiliki tingkat pendidikan lebih rendah (sekolah dasar). Kemampuan untuk memusatkan perhatian selama penyampaian materi penyuluhan (kemampuan konsentrasi) dari para partisipan juga merupakan faktor penting untuk keberhasilan kegiatan ini. Kemampuan untuk berkonsentrasi tersebut dapat dicapai apabila materi tersebut menarik, selain dipengaruhi oleh tingkat pendidikan partisipan. Dengan tingkat pengetahuan yang lebih baik terkait MKJP tersebut, maka diseminasi informasi lebih lanjut oleh Pemerintah sesuai dengan perkembangan terbaru penggunaan MKJP akan menjadi lebih mudah untuk dilaksanakan.

Tabel 2. Hasil Uji Beda Nilai Pretest dan Posttest Kegiatan Pengabdian

\begin{tabular}{cccc}
\hline Karakteristik & Rerata \pm SD & Nilai p \\
\hline Nilai Pretest & 27 & $77.03 \pm 10$. & $0.000^{*}$ \\
Nilai Posttest & & $83.54 \pm 7.9$ & \\
& 2 & & \\
$*$ Uji Wilcoxon, signifikan jika $\mathrm{p}<0.05$ & &
\end{tabular}

Dengan meningkatnya pengetahuan mereka terkait pentingnya program KB MJKP ini, diharapkan kedepannya terdapat perubahan perilaku mereka, yaitu perubahan pilihan dari program KB dengan metode kontrasepsi jangka pendek menjadi jangka panjang. Disamping itu, diharapkan terjadi diseminasi informasi yang lebih luas mengenai MKJP ini di masyarakat di dusun yang sama dengan subjek yang mengikuti kegiatan ini. Untuk mengetahui dampak penyuluhan MKJP tersebut, maka perlu dilakukan evaluasi secara berkelanjutan terhadap diseminasi informasi di setiap dusun yang ada di wilayah kerja Desa Bunut Baok dan sekaligus terhadap cakupan penggunaan metode kontrasepsi jangka panjang di Desa Bunut Baok.

\section{KESIMPULAN DAN SARAN}

Kegiatan pengabdian berupa penyuluhan terkait program keluarga berencana $(\mathrm{KB})$ menggunakan metode kontrasepsi jangka panjang (MKJP) di Desa Bunut Baok, Lombok Tengah, efektif untuk meningkatkan pengetahuan masyarakat yang berpartisipasi dalam kegiatan pengabdian tersebut. Perlu dilakukan evaluasi cakupan pengguna metode kontrasepsi jangka panjang dalam kurun waktu tertentu, misalnya 1-5 tahun kedepan, untuk melihat pengaruh dari peningkatan pengetahuan penduduk Desa Bunut Baok terkait manfaat kontrasepsi MKJP dengan perubahan perilaku mereka, yaitu berupa peningkatan cakupan pengguna MKJP di wilayah desa tersebut.

\section{Ucapan Terima Kasih}

Penulis mengucapkan terima kasih kepada Lembaga Penelitian dan Pengabdian kepada Masyarakat (LPPM) Universitas Mataram, Kepala Desa Bunut Baok, Puskesmas Aikmual, dan DP3AP2KB Kabupaten Lombok Tengah yang telah membantu memfasilitasi terlaksananya kegiatan pengabdian ini. 


\section{DAFTAR PUSTAKA}

Agustina, E., Syechalad M. N., Hamzah A. 2018. Pengaruh jumlah penduduk, tingkat pengangguran dan tingkat pendidikan terhadap kemiskinan di Provinsi Aceh. Jurnal Perspektif Ekonomi Darussalam, 4(2): 265-283.

Amran, Y., Damayanti, R. 2018. Hubungan Antara Motivasi Keluarga Berencana dan Persepsi Terhadap Alat Kontrasepsi Dengan Pola Penggantian Metode Kontrasepsi Di Nusa Tenggara Barat. Jurnal Kesehatan Reproduksi, 9(1): 59-67.

Arifarahmi, A. 2018. Persepsi Akseptor KB Tentang Pemakaian Metode Kontrasepsi Jangka Panjang di Puskesmas Koni Kota Jambi. Jurnal Ilmiah Universitas Batanghari Jambi, 18(3): 559564.

Badan Pusat Statistik. 2016. Statistik Indonesia 2016. Subdirektorat Publikasi dan Kompilasi Statistik.

Febriani, Y. D., Indrawati, F. 2016. Persepsi Pria dan Hubungannya dalam Keikutsertaan Program KB Metode Operatif Pria di Kecamatan Semarang Barat Kota Semarang. Unnes Journal of Public Health, 5(1): 75-83.

Hidayah, N., Lubis, N. 2019. Hubungan Pengetahuan dan Dukungan Suami Terhadap Pemilihan Kontrasepsi Tubektomi. Jurnal Endurance: Kajian Ilmiah Problema Kesehatan, 4(2): 421428.

Muljati, S., Triwinarto, A., Budiman, B. 2011. Determinan Stuntung Pada Anak Usia 2-3 Tahun Di Tingkat Provinsi. PGM, 34(1): 50-62.

Munandar, B. 2017. Demografi dan kependudukan peran informasi keluarga berencana pada persepsi dalam praktik keluarga berencana. Jurnal Swarnabhumi, 2(1): 50-59.

Pasrah, R., Putro, T. S., Indrawati, T. 2014. Efektivitas program keluarga berencana dalam menekan laju pertumbuhan penduduk di Kota Pekanbaru. JOM FEKON, 1(2): 1-15.

Samtyaningsih, D., Ibaadillah, A. A. 2018. Hubungan Pengetahuan Suami Tentang Alat Program Keluarga Berencana di Perumahan Sumberingin Permai Kabupaten Trenggalek. Conference on Innovation and Application of Science and Technology. Malang, September 12.

Suryaningsih, R. 2017. Analisis Pengaruh Faktor Sosial Ekonomi terhadap Tingginya Mortalitas Penduduk. Economics Development Analysis Journal, 6(4): 458-468. 